\title{
Forum
}

\section{Islam in English}

\section{Oludamini Ogunnaike and Mohammed Rustom}

In reality, the subtlety of vessels is from the subtlety of their meanings. And these meanings are augmented by the subtlety of their vessels. Things have become different, while all is yet one, For our spirits are wine, and our forms the vine.

- Ibn al-Fāriḍ ${ }^{1}$

Language is not merely a body of vocabulary or a set of grammatical rules. It is a flash of the human spirit, the means by which the soul of each particular culture reaches into the material world. Every language is an old-growth forest of the ... mind, a watershed of thought, an entire ecosystem of spiritual possibilities.

- Wade Davis ${ }^{2}$

Oludamini Ogunnaike is Assistant Professor of Religious Studies at the College of William and Mary. He holds a PhD in African Studies and the Study of Religion from Harvard University, and was previously Postdoctoral Fellow at Stanford University's Abbasi Program in Islamic Studies. His forthcoming book is entitled Deep Knowledge: Ways of Knowing in Sufism and Ifa, Two West African Intellectual Traditions (Penn State University Press). He also maintains a digital archive of West African Sufi poetry: http://www.waspproject.org.

Mohammed Rustom is Associate Professor of Islamic Studies at Carleton University and Library of Arabic Literature Senior Fellow at the NYU Abu Dhabi Institute. He is the author of the award-winning The Triumph of Mercy: Philosophy and Scripture in Mullā Sadrā (2012), co-editor of The Study Quran: A New Translation and Commentary (2015), translator of Abū Hāmid al-Ghazālìs The Condemnation of Pride and Self-Admiration (2018), and author of Inrushes of the Spirit: The Mystical Theology of 'Ayn al-Qudāt (in press). 


\section{English as an Islamic Language?}

The Quranic revelation had a tremendous impact upon the societies, art, and thought of the various peoples with whom it came into contact. But perhaps nowhere is this influence as evident as in the domain of language, the very medium of the revelation. First, the Arabic language itself was radically and irrevocably altered by the manifestation of the Quran. ${ }^{3}$ Then, as the language of the divine revelation, Quranic Arabic exerted a wide-ranging influence upon the thought and language of speakers of Persian, Turkish, numerous South and South-East Asian languages, and West and East African languages such as Hausa and Swahili.

It is impossible to separate these Islamic languages from the language of the Islamic revelation; and it is nearly impossible to have a conversation in these languages without employing vocabulary, idioms, and even grammatical and syntactical structures derived from the Quran. The fact that the very structures of these languages reverberate with echoes from the language of the Quran and the Hadith is what makes these languages "Islamic" languages. As Toshihiko Izutsu writes:

The whole matter is based on the fundamental idea that each linguistic system-Arabic is one, and Quranic Arabic is another-represents a group of co-ordinated concepts which, together, reflect a particular Weltanschauung, a worldview commonly shared by, and peculiar to, the speakers of the language in question. Thus, Qur'anic Arabic corresponds, in its connotative aspect, to what we may rightly call the Quranic worldview. ${ }^{4}$

This Quranic worldview can also be historically discerned in the various other Islamic languages across the globe, and their idioms, structures, proverbs, and poetry constitute so many well-worn paths of Quranically-inspired thought through the forest of speech. The majority of the speakers of these languages were Muslim and thus the translation and adoption of a Quranic worldview and vocabulary was a relatively organic process resulting from their speakers' engagement with the Quran and Islam's rich traditions of learning and literature.

But when it comes to English, the lingua franca of today's globalized world, the situation is altogether different. Although far more speakers of English are Muslim than typically estimated (when one includes the sizeable Anglophone segments of the Muslim populations of Nigeria, Singapore, Pakistan, India, Bangladesh, and Indonesia), the majority of speakers 
of English are not Muslim. So, the question arises, can English be an Islamic language and, if so, how? In this brief, exploratory essay, we will examine the ways in which English has been and can be used and adapted to bear the weight of the Islamic revelation.

\section{Thought and Language}

Before we discuss the ways in which English has been and can be used as an Islamic language, we should explain why this is important. Why can we not just translate things into English or read Islamic works in translation? Can we not just move the meanings from one language to another as we move objects from one container to another? Why should the language itself have to change?

First and foremost, thought and language on the one hand, and meaning and expression on the other, are not so easily separable-they can and do influence each other. As George Orwell wrote, "if thought corrupts

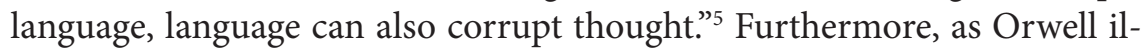
lustrated in his 1984 (particularly in the Appendix on "The Principles of Newspeak"), and as numerous psychological studies have indicated, language does not simply express thought, it shapes it. ${ }^{6}$ In other words, the very structures, metaphors, and idioms of a language preserve and reinforce certain ideas, perspectives, and orientations.

To give but one example among many, historians of philosophy have demonstrated how Aristotle's logic and ontology were profoundly influenced and perhaps even determined by the grammar of Ancient Greek, particularly conjugations of the verb "to be."7 In this vein, one author has noted, "Language is the amber in which a thousand precious and subtle thoughts have been safely embedded and preserved."

Given that language shapes thought and thought shapes and even determines our realities and our very selves, the question of the form of a language is not a facile one. English, like all other languages, carries the marks and contours of its history: the history of the Druids, the Roman Empire, Norse and Norman invasions and migrations, medieval Catholicism, the Protestant reformation, the so-called Enlightenment, the colonial conquests and trade around the world, the Industrial and Scientific Revolutions, and the more recent post-modern and post-colonial social and intellectual formations.

Take, for example, the word "bless." It is derived from the Old Germanic blodison, meaning "to hallow or mark with blood"-a reference to pagan rites of consecration with sacrificial blood. The Old English word 
bletsian/bledsian was used to translate the Latin benedicare and the Greek eulogein, both of which mean to "speak well of or praise," but which were used to translate the Hebrew root $b-r-k$ (meaning "to bend the knee, worship, praise, invoke blessings upon") in Latin and Greek translations of the Old Testament. ${ }^{9}$ Now, "bless" is most commonly used in the idiom, "a blessing in disguise," as well as in response to a sneeze, which itself is a remnant of an ancient Greco-Roman superstition of indeterminate origin.

To give another set of examples, the King James Bible introduced a number of common idioms such as "at their wits' end," "the powers that be," "two-edged sword," "signs of the times," and "skin of my teeth," as well as introducing the Semitic superlative construction "Song of Songs" or "Holy of Holies" into English. Finally, due to the recent scientific and technological revolutions, we now commonly speak of "decompressing," "recharging our batteries," or "getting our wires crossed"-indicating an increasing tendency to think about and relate to ourselves as machines.

These legacies and the shades of meaning they have left imprinted upon English must be considered when attempting to use English with precision in order to ensure that what is said is what is meant, and that what is meant is what is true. As Confucius wrote:

If language is not correct, then what is said is not what is meant; if what is said is not what is meant, then what must be done remains undone; if this remains undone, morals and art will deteriorate; if justice goes astray, the people will stand about in helpless confusion. Hence there must be no arbitrariness in what is said. This matters above everything. ${ }^{10}$

This is why the issue of expressing Islamic worldviews in English is not a trivial one. It requires a deep knowledge of Islamic traditions as well as a profound grasp of English and the traditions that have shaped it. ${ }^{11}$ However, such efforts are not without precedent in other languages and civilizations.

\section{The Han Kitab}

At this juncture, let us introduce a quote:

At the time of our Sage, the clear mandate descended with 6,666 verses and was transmitted to him; then the whole of the Heavenly Classic was complete. The subtlety of this Classic penetrates the secret of the myriad things, going beyond and outside of being and nonbeing. Before heaven and earth, there was real attainment. After heaven and earth, there was the real mandate. This is the utmost teaching of the True Way. ${ }^{12}$ 
Discerning readers will have guessed that this passage was translated into English from Chinese; but it may come as a surprise to many to learn that this text was written in 1642 CE by Wang Daiyu, a Chinese scholar who was born as a Muslim. In this passage, he is describing the all-encompassing reality of the Quran, and the text itself forms part of a larger Chinese-language work that lays out the fundamentals of the Muslim worldview.

While Muslims have been in China since the first Islamic century, and Chinese was widely-spoken and written by substantial Muslim populations in the region, it was in the Qing dynasty ( $17^{\text {th }}$ century CE) that Chinese Islamic scholars began to produce a number of important texts in Classical Chinese that used Neo-Confucian terminology to express and elucidate Islamic metaphysical, cosmological, and ethical ideas. These works are collectively referred to as the "Han Kitab," ${ }^{13}$ and their emergence points to a unique moment in Islamic civilizational and cultural history since it marks one of the few written records we have of minority Muslim authors' articulations of an Islamic worldview in the language and philosophical terminology of a once-different civilization and intellectual tradition. These works directly engaged with the problems and categories of (non-Muslim) Neo-Confucian thought of their day, and thus what these Chinese Muslim authors produced was at once authentically Islamic and authentically Chinese.

The Han Kitab was able to communicate Islam in Chinese primarily through two media. The first of these was through translations and creative adaptations of some of the most important metaphysical texts of Islamic civilization. ${ }^{14}$ The second of these media, an example of which we have seen above, was through the original composition of Islamic texts in the Chinese language and Neo-Confucian idiom as native products of Chinese civilization. ${ }^{15}$

The success of the Muslim Chinese is often cited as an example of what Western, Anglophone Muslims should seek to do-namely, explain and discuss the Islamic tradition in terms that are both profoundly Islamic and British/Canadian/American, etc. We would agree with this assertion, with an important caveat. The pre-modern Chinese example differs from contemporary English in that the pre-modern Chinese (Buddhists, Taoists, Confucians, etc.) held their language and thought worlds to be sacred and symbolic. This is not the case for English - at least not for the vast majority of its contemporary speakers.

Generally, speakers and theorists of English (and other modern European languages) hold that the relationship between the signifier (the name) 
and the signified (the named) is arbitrary and governed by social convention. However, the relationship between word and meaning was generally understood to be more symbolic and even existential by pre-modern speakers of languages such as Chinese and Arabic. That is, in these linguistic contexts, the very spoken or written name of a thing was understood to be intimately connected to the reality of the thing itself. This accounts for the sacred power of these languages - their power of speech, writing, and thought to vehicle the presence of the sacred and to evoke the divine (and sometimes the infernal as well). ${ }^{16}$

While some of the flavour of the sacred character of English can be discerned ${ }^{17}$ in texts such as the King James Bible, the Common Book of Prayer, and works of poets such as Shakespeare and John Donne, English has largely been desacralized. That is, modern English has been profoundly shaped by worldviews in which the sacred has neither place nor true referent, and as a consequence, English is almost never ritually employed in the way that languages such as Arabic, Hebrew, Sanskrit, or Chinese are used.

Moreover, the digital age and social media have rapidly accelerated the degradation and coarsening of the English language. One only has to peruse the comments section beneath any video clip on YouTube to bear witness to this sad phenomenon. Nevertheless, we can still learn from the example of the Muslim Chinese, drawing generally upon the same kinds of principles which guided them and their inquiries, and, as a result, contribute to the re-sacralization of English, that is, the excavation and re-inscription of the sacred back into the English language.

\section{Islam in English}

What, then, would an indigenous presentation of Islam look like in English, the single most diffuse and cosmopolitan language in the world today? It would consist of the creation of Islamic orature and literature in English, and not simply secondary literature on Islam in English or English translations of classical Muslim works. With respect to the latter, it is often wrongly assumed that by translating the great works of the past into English, we are somehow preserving the Islamic tradition in another language. While this is true to a certain degree, there are two dangers to which many translations fall prey. The first danger is that of the profound meanings of the original being lost in translation and new errors being introduced, and this occurs when the translator has not sufficiently penetrated the depths of the original work, and/or lacks facility in, and knowledge in the subtleties of, 
the target language. Far too many translations of Islamic texts suffer from this problem.

Marco Pallis explains how some Tibetan Buddhist traditions addressed this issue:

A Translator, in the sense recognized by the Tibetans, is not to be taken for a mere scholar who, aided by dictionaries turns a certain text from one language to another and leaves it at that. A text interpreted according to the whim of every reader, however uninstructed, is a public danger, since the seed of a whole crop of errors may be sown, which in their turn engender new errors.... One has only to recall some of the ill-founded theories of the Orientalists, due to the distortion of texts by persons who had half-unconsciously read into them their own personal habits of thought, assimilating any words of doubtful meaning to specious equivalents in their own tongue and thus conjuring up an entirely inappropriate set of associations....

To return to the real Translator: his task was indeed a formidable one. His first duty, before putting pen to paper, was to seek out some adept of the doctrine expressed in the treatise which he wished to translate and be properly instructed over a period probably lasting years. Then, having experienced the meaning of that doctrine in his own person, he was prepared to turn the Sanskrit text into Tibetan with more than mere verbal accuracy. That task completed, he carried back the manuscript to Tibet and proceeded to reverse the process he had himself followed, by expounding the doctrine in all its aspects to his own disciples, at the same time placing the text in their hands. Thus the tradition was truly imparted. ${ }^{18}$

The second danger, which is more widespread, is not a question of meaning being "lost in translation," but rather a question of losing the people for whom these translated texts are intended. ${ }^{19}$ In other words, by translating the great texts of the Islamic past into English we are simultaneously doing a great service and a disservice to users of English.

The Muslim Chinese were not content with just carrying over the ideas from their inherited Arabic and Persian texts into their native language. Rather, they often creatively adapted these works to the intellectual contexts and concerns of those for whom they were writing. Moreover, they went beyond these creative translations to produce original works of Islamic thought. They crafted their language to "speak Islam" and their Islamic 
philosophies to "speak Neo-Confucian Chinese," thereby directly addressing their Chinese non-Muslim and Muslim contemporaries' concerns in terms familiar to them.

Likewise, Muslims working in English should not simply be content with translating the books of the past into English. They need to help shape the English language so that it can "speak Islam" and their Islamic philosophies can "speak English"- to speak directly to the concerns of and in terms familiar to contemporary English speakers. That is, it is not enough to accurately translate a classic Islamic work into English; in addition to being accurate, a translation should be accessible, easily understood, and its relevance to the contemporary issues faced by its readers made clear. Even more importantly, just as the scholars of the past wrote accessible works in a variety of languages (particularly Arabic, Persian, and Ottoman Turkish) to address the people, issues, and debates of their times, we too need erudite works of Islamic philosophy, law, theology, and mysticism in accessible English that address the people, issues, and debates of our times.

Because of the profound differences between traditional Islamic worldviews and those currently dominant in the Anglophone world, shaping an English-language Islam will necessitate a modification of the English language even as Islamic worldviews are modified to fit English contexts. As the famous Sufi Junayd said, "The water takes on the colour of the cup." If the cup is dusty or dirty, it must first be rinsed out.

\section{The Anglo Kitab}

The work of shaping an English-language Islam has already begun, most notably through the better translations of the Quran and other important Islamic texts into English. Translators of classical Islamic texts have selected and thus "created" a "new" vocabulary of English words to express Islam-specific terms: "vicegerent" (khalifa), "ablution" ( wud $\left.\bar{u}_{\bar{u}}\right)$ ), "remembrance" or "invocation" (dhikr), "self-disclosure" (tajalli)), "the Real" (alHaqq), etc. have all entered into academic and popular Muslim discourse. Such acts of translation have influenced and altered the way we understand and use many English words, even as these English words have shaped and influenced the way in which these Islamic terms have been received and understood. Seyyed Hossein Nasr and William Chittick deserve special mention in this regard for their thoughtful and considered selection of an English vocabulary suitable to express the ideas of Islamic philosophical and mystical traditions, ${ }^{20}$ choosing English-language terms on the basis 
of their etymologies and traditional usage in religious and philosophical contexts.

What we also need more of are works like those of the authors of the Han Kitab such as Liu Zhi and Wang Daiyu. We can discern the beginnings of such works in English in the later speeches of Malcolm X, ${ }^{21}$ and in certain passages of Sherman Jackson's work, both of which draw on the powerful English oratorical traditions of the Black American church; as well as in the writings of the late Charles Le Gai Eaton, the late Martin Lings, and the Contentions of Abdal Hakim Murad (Tim Winter), all three of which employ a high register of British literary and academic English to good effect.

Islamic English should not have a tension between "speaking to people in a language which they can understand" and speaking in a language which conforms to the Quranic worldview and reflects the beauty of its meanings. What we have in mind is thus not akin to the various Muslim "self-help" books which try to shoe-horn Quranic verses, Prophetic sayings, and quotes from past Muslim sages into the shallow, transactional, and individualistic moralism (and terrible prose) of the genre; the ill-informed, made-for-airport-bookstore screeds of the likes of Irshad Manji; nor the insular discourses of the self-appointed internet 'ulama'. The works of the Han Kitab were profound, eloquent, and deeply grounded in both the Islamic and Neo-Confucian traditions upon which they drew. The works of the "Anglo Kitab" should be no different, drawing upon and springing from a profound knowledge of Islamic and English literary and wisdom traditions.

Such an endeavor should not be limited to prose works of philosophy, ethics, and spirituality-one of the most characteristic features and glories of the literatures of Islamic languages around the world is their poetry. There is no Islamic language that does not have a rich poetic tradition, and these traditions tend to share certain features: metre, rhyme, and rich symbolic languages based on Islamic cosmology, Quranic imagery, and the language of love. English will truly be an Islamic language when we have a robust poetic tradition of this kind.

Islamic literatures have also been characterized by their epics (which are often poems themselves or highly poetic), imaginative folk tales, and philosophical allegories that can combine the thought-provoking creativity of the best of English-language sci-fi (such as Phillip K. Dick), the allegory of Dante, the broad mythological sweep of Tolkien, and the humour and wit of a Mark Twain or Oscar Wilde. When we have original, English-lan- 
guage Islamic epics, philosophical allegories (in the tradition of Ibn Tufayl's Hayy ibn Yaqzān), wise and funny folktales (think Sindbad, Baybars, and Juhā/Mullā Nașruddīn in the idiom of Brer Rabbit), then we will have an English literature that is truly Islamic and an Islamic literature that is truly English. Among the pioneers in this endeavour, to name but a few, are Martin Lings, the late Daniel Abdal-Hayy Moore, Baraka Blue, Alexis York Lumbard, and Amir Sulaiman.

\section{By Way of a Conclusion}

The foregoing should make it clear that what is most needed in our times are English-language works that can express and embody the Islamic worldview, not just describe it. That is, Muslims need to seriously start thinking about producing works on truth, beauty, goodness, and justice that are written from Islamic perspectives, and not just about these perspectives. In other words, as much as there is a need for people who can write books about such great Muslim intellectuals as Ibn Sīnā, Ghazālī, 'Ayn al-Quḍāt, Ibn 'Arabī, and Mullā Șadrā, we need people who can write like them in English and for English-language contexts, and in a variety of genres. ${ }^{22}$ Such a development is necessary for the contemporary English-speaking Muslim community, not only in Australia, North America, and the United Kingdom, but, given the global dominance of English, for the umma as a whole.

We hope the brief reflections in this essay will serve as encouragement and inspiration to those young men and women who have the capacity and talent to help craft an English-language Islam. In the words of Rūmì:

Hurry! Speak fresh words, so that the two worlds may be refreshed. ${ }^{23}$ 


\section{Endnotes}

1. Khamriyya: http://www.adab.com/modules.php?name=Sh3er\&doWhat=sh qas\&qid=15405.

2. "An Interview with Anthropologist Wade Davis," Radio Expeditions, NPR: https://www.npr.org/programs/re/archivesdate/2003/may/mali/davisinterview.html.

3. As Toshihiko Izutsu has demonstrated, if we compare the Quranic vocabulary with pre-Islamic Arabic, we immediately notice that there is "one supreme focus-word, Allah, which presides not only over one particular semantic field within the vocabulary, but over the entire vocabulary comprising all the semantic fields, that is, all the smaller conceptual systems that fall under it" (Izutsu, God and Man in the Quran [Kuala Lumpur: Islamic Book Trust, 2008], 37).

4. Izutsu, Ethico-Religious Concepts in the Qur'an (London: McGill-Queen's University Press, 2002), 250.

5. George Orwell, "Politics and the English Language" in The Collected Essays, Journalism and Letters of George Orwell, ed. Sonia Orwell and Ian Angos (New York: Harcourt, Brace, Javanovich, 1968), 4:137.

6. Lera Boroditsky, "How Language Shapes Thought: The Languages We Speak Affect our Perceptions of the World," Scientific American (February 2011), 63-65.

7. See Charles Kahn, “The Greek Verb 'To Be' and the Concept of Being," Foundations of Language 2, no. 3 (1966): 245-265.

8. R. C. Trench, "Extract from 'Introductory Lecture" in The Origin of Language, ed. Roy Harris (Bristol: Thoemmes Press, 1996), 6.

9. See https://www.etymonline.com/search?q=bless.

10. This is a paraphrase of Confucius' Analects 13.3. See James Legge (trans.), Confucian Analects: The Great Learning, and the Doctrine of the Mean (New York: Dover Publications, 1971), 263-264.

11. In certain cases, however, this knowledge can be more or less implicit, much as those who know the Quran well are aware of or rather "feel" the different shades of meaning associated with a given Quranic term without being aware of how they know this.

12. Cited from Sachiko Murata, The First Islamic Classic in Chinese: Wang Daiyu's Real Commentary on the True Teaching (Albany: State University of New York Press, 2017), 76.

13. Zvi Ben-Dor Benite, The Dao of Muhammad: A Cultural History of Muslims in Late Imperial China (Cambridge, MA: Harvard University Asia Center, 2005), 119.

14. See Murata, Chinese Gleams of Sufi Light: Wang Tai-yü's Great Learning of the Pure and Real and Liu Chih's Displaying the Concealment of the Real 
Realm (Albany: State University of New York Press, 2000); Murata, William Chittick, and Tu Weiming, The Sage Learning of Liu Zhi: Islamic Thought in Confucian Terms (Cambridge, MA: Harvard University Asia Center, 2009); Kristian Petersen, Interpreting Islam in China: Pilgrimage, Scripture, and Language in the Han Kitab (New York: Oxford University Press, 2018).

15. For a recent, brief inquiry into this phenomenon, see John Walbridge, "Breaking the Language Barrier: The Han Kitab and the Implications of Radical Translation," Renovatio, December 19, 2018, https://renovatio.zaytuna. edu/article/breaking-the-language-barrier.

16. This is the perspective that explains the efficacy of talismans, ruqyas, and other uses of language to interact with spiritual entities.

17. This is especially true for those populations whose adoption of English is relatively more recent, such as in Sub-Saharan Africa.

18. Pallis, Peaks and Lamas (Washington, D.C: Shoemaker and Hoard, 1949), 72-74. The analogy to the situation of the Anglophone Muslim or scholar of Islam is clear, and we would do well to follow the example of the Tibetans (as some have).

19. Put differently, we not only lose meanings in translation, but also people. We are indebted to Nosheen Mian for this important insight.

20. For a few examples, see Nasr, Islamic Life and Thought (Albany: State University of New York Press, 1981) and Islamic Philosophy from Its Origins to the Present: Philosophy in the Land of Prophecy (Albany: State University of New York Press, 2006); Chittick, The Sufi Path of Knowledge: Ibn al-Arabìs Metaphysics of Imagination (Albany: State University of New York Press, 1989) and Divine Love: Islamic Literature and the Path to God (New Haven: Yale University Press, 2013).

21. See https://www.youtube.com/watch?v=5fnPXw-Tn6I.

22. Some examples of what we are suggesting can be found in Chittick, Science of the Cosmos, Science of the Soul: The Pertinence of Islamic Cosmology in the Modern World (Oxford: Oneworld, 2007); Nasr, The Garden of Truth: The Vision and Promise of Sufism, Islam's Mystical Tradition (New York: HarperOne, 2007); Oludamini Ogunnaike, "Shining of the Lights and the Veil of the Sights in the Secrets Bright': An Akbari Approach to the Problem of Pure Consciousness," Journal of the Muhyiddin Ibn 'Arabi Society 61 (2017): 17-42; Mohammed Rustom, "The End of Islamic Philosophy," Sacred Web 40 (2017): 131-167.

23. Dìwān-i Shams-i Tabrīzì: https://ganjoor.net/moulavi/shams/ghazalsh/ $\operatorname{sh} 546 /$. 